\title{
THE EFFECT OF PHYSICAL EXERCISE ONTHE REHABILITATION QUALITY OF HUMAN WAIST DYSFUNCTION
}

\author{
O EFEITO DO EXERCÍCIO FÍSICO NA QUALIDADE DA REABILITAÇÃO DA DISFUNÇÃO DA \\ CINTURA HUMANA \\ EL EFECTO DEL EJERCICIO FÍSICO EN LA CALIDAD DE REHABILITACIÓN DE LA DISFUNCIÓN \\ DE LA CINTURA HUMANA
}

\author{
Fanfan $\mathrm{Li}^{1}$ (ID \\ (Physical Education Professional) \\ 1. Nanjing Media College, Nanjing, \\ Jiangsu, 210000, China. \\ Correspondence: \\ Nanjing Media College, \\ Nanjing, Jiangsu, 210000, China. \\ lifanfan01132@163.com.
}

\begin{abstract}
Introduction: Human motor dysfunction can affect the quality of life, especially waist dysfunction. And an effective means to improve muscle strength during exercise. Object: This article compares and analyzes the effectiveness of human muscle exercise on the decline in quality of life caused by motor dysfunction. Method: The article divides patients with motor dysfunction into trunk isokinetic training group (experimental group) and waist and abdominal muscle functional training group (control group), and comparative analysis of related indicators before and after treatment. Results: Before treatment, the specific indicators of the two were different $(P>0.05)$. After treatment, the patients' quality of life indicators and motor function indicators were significantly different $(P<0.05)$. Conclusion: Exercise has an obvious curative effect for patients with human motor dysfunction, and it is worthy of clinical promotion. Level of evidence Il; Therapeutic studies - investigation of treatment results.
\end{abstract}

Keywords: Sports; Abdominal Muscles; Functional Exercise; Low Back Pain; Muscle Strength; Rehabilitation.

\section{RESUMO}

Introdução: A disfunção motora humana pode afetar a qualidade de vida, principalmente a disfunção da cintura. E um meio eficaz de melhorar a força muscular é o exercício. Objetivo: este artigo compara e analisa a eficácia do exercício muscular humano no declínio da qualidade de vida causado por disfunção motora. Método: $O$ artigo divide os pacientes com disfunção motora em grupo treinamento isocinético de tronco (grupo experimental) e grupo treinamento funcional de cintura e músculos abdominais (grupo controle), e análise comparativa dos indicadores relacionados antes e após o tratamento. Resultados: Antes do tratamento, os indicadores específicos dos dois eram diferentes $(P>0,05)$. Após o tratamento, os indicadores de qualidade de vida e indicadores de função motora dos pacientes foram significativamente diferentes $(P<0,05)$. Conclusão: O exercício tem um efeito curativo óbvio para pacientes com disfunção motora humana e é digno de promoção clínica. Nível de evidência ll; Estudos terapêuticos - investigação dos resultados do tratamento.

Descritores: Esportes; Músculos Abdominais; Exercício Funcional; Dor Lombar; Força Muscular; Reabilitação.

\section{RESUMEN}

Introducción: La disfunción motora humana puede afectar la calidad de vida, especialmente la disfunción de la cintura. Y un medio eficaz para mejorar la fuerza muscular es el ejercicio. Objeto: Este artículo compara y analiza la efectividad del ejercicio muscular humano sobre el deterioro de la calidad de vida causado por la disfunción motora. Método: El artículo divide a los pacientes con disfunción motora en grupo de entrenamiento isocinético del tronco (grupo experimental) y grupo de entrenamiento funcional de cinturay músculos abdominales (grupo control), y análisis comparativo de indicadores relacionados antes y después del tratamiento. Resultados: Antes del tratamiento, los indicadores específicos de los dos eran diferentes ( $P>0.05)$. Después del tratamiento, los indicadores de calidad de vida de los pacientes y los indicadores de función motora fueron significativamente diferentes $(P<0,05)$. Conclusión: El ejercicio tiene un efecto curativo obvio para los pacientes con disfunción motora humana yes digno de promoción clínica. Nivel de evidencia ll; Estudios terapéuticos: investigación de los resultados del tratamiento.

Descriptores: Deportes; Músculos Abdominales; Ejercicio Funcional; Dolor de la Région Lumbar; Fuerza Muscular; Rehabilitación. 


\section{INTRODUCTION}

Low back pain is a syndrome in which pain and discomfort in the lower back, lumbosacral area and buttocks are the main symptoms. $80 \%$ of low back pain has neither nerve root involvement nor serious disease called non-specific low back pain. ${ }^{1}$ The pathological mechanism of non-specific low back pain (NLBP) is complicated, and its treatment methods include physical therapy, drug therapy, surgical therapy, and psycho-behavioral therapy. Exercise therapy is a type of physical therapy. ${ }^{2}$ This study compares and analyzes the different effects of trunk isokinetic strength training and waist and abdominal muscle functional training on NLBP, and strives to find the best trunk muscle strength training method for NLBP rehabilitation therapy, and provides a theoretical reference for the prevention and treatment of NLBP. ${ }^{3}$

\section{METHOD}

\section{General information}

The research object of this thesis is 40 patients who were admitted to the outpatient department of an orthopedic hospital and diagnosed with nonspecific low back pain. With the patients'informed consent, the selected patients were randomly divided into trunk isokinetic training group (experimental group) and waist and abdominal muscle functional training group (Control group). There were no significant differences between the two groups in terms of gender, age, and disease course.

\section{Selection criteria}

The diagnostic criteria are based on the proposed low back pain, recurrent episodes or chronic recurring aggravation; no systemic diseases; psychosocial factors that do not make the pain amplify or prolong, no nerve involvement.

\section{METHOD}

\section{Treatment methods}

Lumbar and abdominal muscles functional exercise: We mainly focus on lumbar muscle training, abdominal muscle training, and lumbar and abdominal muscle training.

Trunk isokinetic training: the training equipment is the CYBEX-6000 isokinetic training system. The subject stood upright with both feet placed on the adjustable pedals. ${ }^{4}$ The isokinetic device's rotation axis was placed at the intersection of the mid-axillary line and the lumbosacral region, approximately $3.5 \mathrm{~cm}$ below the upper edge of the iliac crest. ${ }^{5}$ Fix the subject's chest, pelvis and lower limbs. When the lower limbs are fixed, keep the vertebrae slightly flexed by $15^{\circ}$, allowing their range of motion to be between $80^{\circ}$ flexion and $10^{\circ}$ extension.

\section{Index test method}

1) Pain Visual Score (VAS) test method. 2) Finger-to-ground distance (FFD) test method. 3) Trunk muscle strength testing method. Calculate the peak torque (PT) and relative peak torque (PT/BW) of the two groups of trunk flexors and extensors at different angular velocities. 4) The paper adopts the Owelty Low Back Pain Dysfunction Scale (OSW).

\section{The principle of exercise on the waist flexion and isokinetic extension system}

Assuming that $z(k)$ represents the practical measurement set of the athlete's waist flexion and extension isokinetic muscle strength confirmed at time $\mathrm{k}, H(V, B)$ represents the mutation probability of mitochondrial DNA during aging, and $(m, n, p, Y)$ represents labor intensity, ${ }^{6}$ body mass index, sunshine time, environmental temperature, For variable indicators such as humidity, formula (1) is used to construct an observation equation for the stability of the vertebral joints in elderly women

$$
J[U, C]=\frac{-u_{j} 1 n-\partial(m, n, p, Y)}{z[k] g k \times H(V, B)}
$$

The above formula $u_{j}$ represents the decline of the athlete's waist isokinetic muscle strength due to reduced estrogen, reduced elderly activity, diet and nutrition imbalance, and other reasons. $\partial$ represents a sample of isokinetic muscle strength of waist flexion and extension with average bone mass, representing the scale factor.

$$
P(k)=\frac{\omega \oplus l}{K \times \gamma(m, b)} \times J[U, C]
$$

In the formula, K represents the distribution characteristics of various factors related to the decline of the athlete's waist flexion and extension isokinetic muscle strength. $\gamma(m, b)$ represents the statistical distance between the observed state measurement and the predicted value. ${ }^{7}$

Assuming that $\ell, \Upsilon$ represents the dynamic stability of the right and left feet at the moment of landing, and $\tau$ represents the athlete's daily habit of squatting, then use equation (2) to change the stability of the athlete's vertebral joints during squatting

$$
\Psi(C)=\frac{[\ell \times \Upsilon]^{\tau}}{d(m)} \square S(P, O)
$$

The formula $d(m)$ represents the ratio of speed to $\omega_{(x)}$, and $S(P, O)$ represents gait parameters such as squatting speed, step length, and step width.

Hypothesis $j, k, c, b, l$ represents that the athlete has primary osteoporosis factors such as decreased estrogen and imbalance of diet and nutrition. $x$ represents the practical measurement set of the dynamic stability of the athlete's waist flexion and extension isokinetic muscle strength confirmed at the time $t+1$. Then use formula (4) to calculate the absolute difference of the different characteristic parameters of the athlete's waist flexion and extension isokinetic muscle strength decline.

$$
\xi(S, P)=S[\xi] \times \frac{[j, k, c, b, l]}{X(t+1)} \delta(Y)
$$

The formula $S[\xi]$ represents the state measurement value corresponding to each practical observation and $\delta(Y)$ represents the correlation probability of $X$ and the data correlation factor of the athlete's waist flexion and extension isokinetic muscle strength decline probability data.

Assume that $c(d)$ represents the different labor intensity of the athletes, $v(d)$ represents the different BMls of the athletes, and $f(d), g(d)$ represents the temperature and humidity of the environment. We use formula (5) to describe the influence process of squatting on the decline of the athlete's waist flexion and extension isokinetic muscle strength

$$
R(M)=\frac{[c(d), v(d), f(d), g(d)]}{\theta(P) \oplus[S(j)] \times u_{(j)}} \times v_{(G)}
$$

The formula $\theta(P)$ represents the discriminant function of the influencing factors, $S(j)$ represents the optimal difference factor, and $v_{(G)}$ represents the absolute difference of the characteristic indicators of each recession influencing factor. With the increase of age, $s\left(q_{\sigma}\right)$ the change process between the serum estradiol level and the sulfite content in patients with osteoarthritis is synovial fluid.

\section{Statistical analysis}

The data was processed by statistical software SPSS15.0, measurement data were expressed as mean \pm standard deviation, comparison between groups was performed by t-test, and $P<0.05$ indicated a significant difference. 


\section{RESULTS}

\section{Changes in VAS and FFD before and after the two groups of experiments}

It can be seen from Table 1 that before the experiment, there was no significant difference between the two groups of VAS and FFD $(P>0.05)$; after the experiment, the two groups of VAS and FFD were significantly reduced, which was significant compared with before the experiment $(P<0.05)$; After the experiment, there is no significant difference between the two groups of VAS and FFD.

\section{Changes in the muscle strength of trunk flexors and exten- sors before and after the two groups of experiments}

Before the experiment, there was no significant difference between the two groups of PT60, PT90, PT/BW60, and PT/BW90 (P>0.05); after the experiment, at different angular velocities of $60 \% \mathrm{~s}$ and $90 \%$, the two groups of trunk flexion and extension The peak torque (PT) and peak torque-to-weight ratio (PT/BW) of muscle groups were significantly higher than those before the experiment, with significant differences $(P<0.05)$; after the experiment, the two groups of PT60, PT90, PT/BW60, PT/There was no significant difference between the BW90 groups ( $P>0.05)$. (Table 2 and 3 )

\section{Changes in OSW integral index before and after the two groups of experiments}

It can be seen from Table 4 that compared with before the experiment, the OSW of the two groups was significantly reduced after the experiment, which was significant $(P<0.05)$. After the experiment, there was no significant difference between the two groups of OSW.

Comparison of comprehensive statistical validity of different models

Compare the two models to calculate the error (\%), stability (\%) and efficiency (\%) of the squat-up exercise on the waist flexion and extension

Table 1. Comparison of VAS and FFD of pain visual scores between the two groups before and after the experiment.

\begin{tabular}{c|c|c|c|c}
\hline \multirow{2}{*}{ Group } & \multicolumn{2}{|c|}{ VAS } & \multicolumn{2}{c}{ FFD (cm) } \\
\cline { 2 - 5 } & $\begin{array}{c}\text { Before the } \\
\text { experiment }\end{array}$ & $\begin{array}{c}\text { After the } \\
\text { experiment }\end{array}$ & $\begin{array}{c}\text { Before the } \\
\text { experiment }\end{array}$ & $\begin{array}{c}\text { After the } \\
\text { experiment }\end{array}$ \\
\hline Test group & $4.85 \pm 0.92$ & $1.22 \pm 1.42$ & $9.65 \pm 11.34$ & $2.39 \pm 4.67$ \\
\hline Control group & $5.21 \pm 1.26$ & $1.31 \pm 1.44$ & $9.72 \pm 14.45$ & $3.61 \pm 6.42$ \\
\hline
\end{tabular}

Table 2. Comparison of trunk flexor peak moments before and after the two groups at different angular velocities.

\begin{tabular}{c|c|c|c|c}
\hline \multirow{2}{*}{ Group } & \multicolumn{2}{|c|}{ PT60 } & \multicolumn{2}{c}{ PT90 } \\
\cline { 2 - 5 } & $\begin{array}{c}\text { Before the } \\
\text { experiment }\end{array}$ & $\begin{array}{c}\text { After the } \\
\text { experiment }\end{array}$ & $\begin{array}{c}\text { Before the } \\
\text { experiment }\end{array}$ & $\begin{array}{c}\text { After the } \\
\text { experiment }\end{array}$ \\
\hline Test group & $41.04 \pm 33.78$ & $68.66 \pm 28.87$ & $24.61 \pm 20.54$ & $53.35 \pm 23.11$ \\
\hline Control group & $29.22 \pm 31.45$ & $54.01 \pm 39.09$ & $18.73 \pm 21.63$ & $37.50 \pm 32.69$ \\
\hline
\end{tabular}

Table 3. Comparison of relative peak moments of trunk flexors before and after the two groups at different angular velocities.

\begin{tabular}{c|c|c|c|c}
\hline \multirow{2}{*}{$\begin{array}{c}\text { Group } \\
\text { test group }\end{array}$} & \multicolumn{2}{|c|}{ PT/BW60 } & \multicolumn{2}{c}{ PT/BW90 } \\
\cline { 2 - 5 } & $\begin{array}{c}\text { Before the } \\
\text { experiment }\end{array}$ & $\begin{array}{c}\text { After the } \\
\text { experiment }\end{array}$ & $\begin{array}{c}\text { Before the } \\
\text { experiment }\end{array}$ & $\begin{array}{c}\text { After the } \\
\text { experiment }\end{array}$ \\
\hline Control group & $26.99 \pm 21.16$ & $47.32 \pm 20.42$ & $16.56 \pm 12.71$ & $37.25 \pm 18.11$ \\
\hline Group & $20.62 \pm 21.97$ & $35.91 \pm 25.27$ & $12.75 \pm 14.83$ & $25.25 \pm 42.48$ \\
\hline
\end{tabular}

Table 4. Comparison of OSW score index before and after the two groups of experiments.

\begin{tabular}{c|c|c|c}
\hline Group & Number of cases & $\begin{array}{c}\text { Before the } \\
\text { experiment }\end{array}$ & $\begin{array}{c}\text { After the } \\
\text { experiment }\end{array}$ \\
\hline test group & 20 & $25.08 \pm 0.87$ & $12.22 \pm 0.42$ \\
\hline Control group & 20 & $24.12 \pm 0.69$ & $13.89 \pm 0.54$ \\
\hline
\end{tabular}

isokinetic muscle strength decline. The comprehensive validity of the statistics of the influence of squatting exercise on the decline of waist flexion and extension is better than the comprehensive validity of squatting exercise's influence on the decline of wrist flexion and extension. Based on the calculated results, a model of the influence of squat-up exercise on the decline of waist flexion and extension isokinetic muscle strength was set. It guarantees the comprehensive validity of the statistics of the influence of the squat-up exercise on the waist flexion and extension isokinetic muscle strength decline of this paper's model.

\section{DISCUSSION}

NLBP has diverse clinical manifestations and lacks specific imaging support, often misdiagnosed, leading to unsatisfactory treatment effects. Studies believe that the lumbar spine's segmental instability caused by the weakening of the back muscles and abdominal muscles is the leading cause of NLBP, and the occurrence of NLBP is co-occurring with the weakening of trunk muscle strength and endurance. Some scholars have found that the weakness of the back muscle endurance and the instability of the lumbar spine indicates the occurrence of low back pain. George believes that treatment in the acute phase is to relieve pain and restore daily functions, while the goal of treatment in the chronic phase is to return to exercise and prevent recurrence. ${ }^{8}$ Compared with traditional medicine, surgery, physical factors, and other treatment methods, it has non-injury, specific, and compelling characteristics. However, which trunk muscle function exercise method is more effective has not been reported in the literature.

Studies have reported that nonspecific low back pain symptoms are mainly manifested by pain, dysfunction, and decreased muscle strength of the waist and abdominal muscles. In this study, PT and PT/BW are the torque indicators in the isokinetic test, reflecting the strength of the trunk flexors and extensors. OSW has high validity and reliability and is widely used in spinal surgery and observation of conservative treatment effects, and it is regarded as the gold standard. The results of this study show that, compared with before the experiment, the VAS, FFD, and OSW indexes of the trunk isokinetic training group and the waist and abdominal muscle functional training group were significantly reduced after the experiment, while those at different angular velocities of $60 \% \mathrm{~s}$ and $90 \%$ s. The values of PT and PT/BW are significantly increased, and both have significant differences, suggesting that both training methods can relieve pain, improve NLBP dysfunction, and strengthen the patient's trunk muscle strength.

The trunk muscle plays an essential role in maintaining the spine's stability, and its stability imbalance leads to low back pain. The trunk extensor's weakness is the key to the occurrence and development of chronic low back pain. Studies have shown that low back pain that lasts for one month will reduce the strength of trunk flexion and extensor, and the decline of trunk flexion and extensor strength will aggravate the symptoms of low back pain. This repeated formation of a vicious circle.

\section{CONCLUSION}

The above research results show that different training methods and training cycles can effectively improve the lower back's muscle strength. This study shows that isokinetic training and functional exercises of the waist and abdominal muscles can effectively relieve the pain of patients with nonspecific low back pain, improve the patients' waist dysfunction, and increase the patients' muscle strength' waist and abdominal muscles. They have significant effects on the treatment of NLBP, but the two methods are effective in treating NLBP. There is no significant difference in efficacy.

$\overline{\text { The author declare no potential conflict of interest related to this article }}$ 


\section{REFERENCES}

1. Ng AK, Hairi NN, Dahlui M, SuTT, Jalaludin MY, Majid HA. The longitudinal relationship between dietary intake, physical activity and muscle strength among adolescents. Br J Nutr. 2020;124(11):1207-18

2. Nataloka SW, Sulaiman S, Rahayu S. The impacts of body sculpting exercise and age on body fat and waist circumference. Journal of Physical Education and Sports. 2019;8(4): 76-81.

3. Agbonhalor El, Subulade AT. Effects of 10-weeks strength training program on pain intensity, muscle endurance and kinesophobia in patients with nonspecific low back pain. Turkish Journal of Kinesiology. 2020;6(1): 40-8

4. Zhang X, Gu X, Zhang T, Caçola P, Wang J. Are movement behaviors and fundamental motor skills associated with fitness and fatness in early childhood? Findings from the 2012 NHANES National Youth Fitness Survey. Pediatr Exerc Sci. 2020;32(1):9-15.
5. Motta C, de Lira CAB, Vargas VZ, Vancini RL, Andrade MS. Profiling the isokinetic muscle strength of athletes involved in sports characterized by constantly varied functional movements performed at high intensity: a cross-sectional study. PM R. 2019;11(4):354-62.

6. Nie S, Ma B, Song J. Study on the Influence and Difference of Taijiquan and Five-animal Exercise on College Students' Ankle Muscle Strength. IJACT. 2020;8(3): 307-15.

7. Kim DW, Hassett LM, Nguy V, Allen NE. A comparison of activity monitor data from devices worn on the wrist and the waist in people with parkinson's disease. Mov Disord Clin Pract. 2019;6(8):693-9.

8. Witwit BM. Effect of using Core Stability training on the defense effectiveness against Waist Turnover in fight position from blow for Wrestlers. ISJPES. 2020 [cited 2021 Jun 9];8(1):9-32. Available from: https://isjpes.journals.ekb.eg/article_89151_27aa67761e079d7d25586837acad3800.pdf 